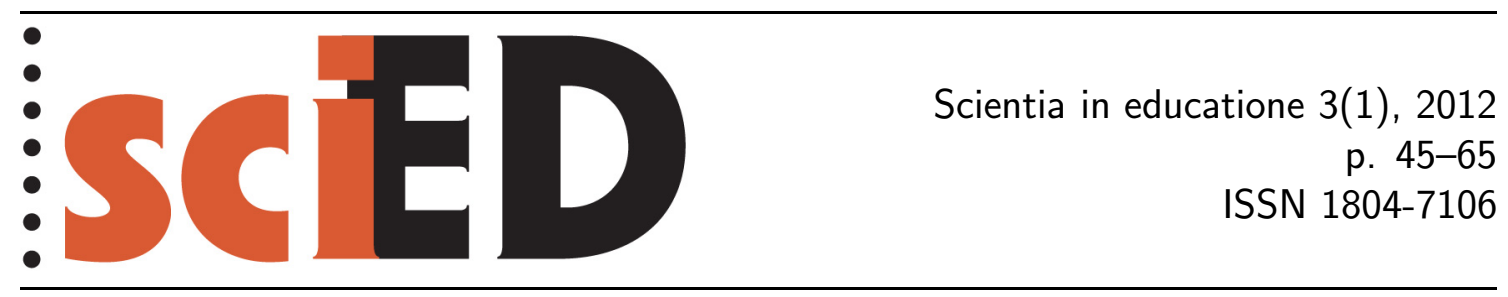

\title{
Matematická přesvědčení učitelů matematiky: přehled mezinárodního výzkumu
}

\author{
Jana Žalská
}

\begin{abstract}
Abstrakt
Tato přehledová studie slouží jako úvod do problematiky matematických přesvědčení1 učitelů matematiky tak, jak je studuje mezinárodní výzkum. Přináší jak teoretická východiska, tak praktické př́klady jednotlivých studií, týkajících se daných jevů a konkrétních př́padů. Zvláště se zaměřuje na vztah mezi danými přesvědčeními a vzděláváním učitelů matematiky, na některé metodologické problémy spojenými s výzkumem a na studie poskytující typologie matematických přesvědčení učitelů. Jsou uvedeny některé relevantní výsledky z oblasti českého výzkumu a zasazeny do mezinárodního kontextu. Dále studie zmiňuje další proudy a perspektivy spojené s tématem matematických přesvědčení učitelů matematiky.
\end{abstract}

Klíčová slova: přesvědčení učitelů, matematická přesvědčení, vzdělávání učitelů, výuka matematiky, metakognitivní jevy.

\section{Mathematics Teachers' Mathematical Beliefs: A Comprehensive Review of International Research}

\begin{abstract}
This review of literature provides a comprehensive introduction to the research on the mathematical beliefs of mathematics teachers. It both describes the theoretical framework and provides practical illustrations of studies and relevant phenomena. Special attention is given to the relationship between mathematical beliefs and teacher professional development, to critical methodological issues particular to the research, and to teacher

\footnotetext{
${ }^{1}$ Pojem přesvědčení je zde použit ve smyslu anglického pojmu belief tak, jak je zaveden v tematicky zaměřené zahraniční literatuře. $V$ české odborné literatuře se používají i pojmy jako nazírání, názor, mínění. Ačkoli slovo přesvědčeni se blíží spíše anglickému conviction, oborová anglicky psaná literatura pracuje nejčastěji s pojmem belief a užívá conviction spíše jako kvalitativní charakteristiku, sílu přesvědčení, např. „,degree of conviction“ (str. 259) v práci Philippa (2007). Vzhledem k problematice vymezení jednotlivých základních pojmů, se kterou je čtenář seznámen v úvodní části textu, se pojem přesvědčení jeví jako vhodný pro daný obor výzkumu. Přestože se text zabývá konkrétně matematickými přesvědčeními učitelů matematiky, právě úvodní část věnovaná problematice pojmu beliefs může pomoci některé základní konstrukty vymezit i pro obecnějšś okruh zájmu.
} 
belief typological studies. Relevant research in the Czech Republic is outlined and situated within the international body of literature. Further perspectives and interests of investigation, as related to the mathematical beliefs of teachers, are suggested.

Key words: teachers' beliefs, teacher development, mathematics teaching practices, meta-cognitive phenomena, mathematical beliefs. 
To understand the decisions, actions, practice and development patterns of mathematics teachers as related to their teaching and to the learning of their students, it is necessary to engage not only in the study of cognitive and mathematical aspects of teaching and learning but also of broader socio-psychological issues. The study of beliefs belongs to the latter category. In the past three decades, the subject of beliefs has become the focus of a considerable body of research projects, studies, theories and publications in the field of mathematics education. Given the broadness of the concept itself (beliefs, conceptions, views, perceptions, etc.) and the potential place and role in a structure of pedagogical, psychological and philosophical phenomena it is assigned, this is hardly surprising. Thus, while this substantial amount of research activity has produced an appropriate accumulation of findings, theories, hypotheses and other insights into the world of mathematics teaching, mathematics learning, mathematics teacher education, and mathematics education research itself, such mass of accumulated knowledge and experience is far from homogenous. In the following pages we attempt to provide the reader with a comprehensive overview of this particular area of research, restricted to the notion of mathematics teachers' beliefs. ${ }^{2}$ By the term mathematical beliefs we will understand here the beliefs concerning educational context: beliefs about mathematics, mathematics teaching and mathematics learning.

\section{A BRIEF HISTORICAL OVERVIEW}

Although we can trace an interest in teachers' beliefs further back (one of the most quoted researchers in the area of beliefs are Rokeach and Green ${ }^{3}$ ), it was in the 1980's that the first theoretical and experimental work took place (Cooney, 1985; Thompson, 1984; Ernest, 1989; Schoenfeld, 1989; Kuhs, Ball, 1986; Brousseau, Freeman, 1988, among others), preceded and complemented by developments in research in cognitive and social processes (e.g., Polya, 1965; Rokeach, 1968; Fischbein, Ajzen, 1975; Schoenfeld, 1983; Schoenfeld 1988), as regards a teacher's beliefs and attitudes. Then in the early 1990's, influential syntheses were published by Pajares (1992) on teachers' beliefs, Thompson (1992) on mathematics teachers' beliefs and Dossey (1992) on teachers' beliefs about the nature of mathematics. These gave both the academic acknowledgement of teacher beliefs playing a major role in the processes of learning and teaching, and grounds for further research. The attention of research on mathematics teachers shifted from purely cognitive and mathematical to a domain that allows for sociological and psychological consideration, for so-called "meta-issues" (Skott, 2009, p. 45).

Within the area of mathematics education, the investigation into teachers' beliefs was further theoretically framed by Ernest (1991), Schoenfeld (1992), Lerman (1990), Bishop (1988), Perry (1970), Kagan (1992), and others. The research activity gained momentum. In 2002, a first book on mathematics belief research, Beliefs: a hidden variable in mathematics education? (Leder et al., 2002), was published by Kluwer, compiling and reviewing past research on three subjects: the concept of belief, teachers' mathematical beliefs and students' mathematical beliefs. In 2004, Pehkonen (2008) reported that the PME proceedings of the past decade contained

\footnotetext{
${ }^{2}$ As distinguished from the beliefs of pupils or students or of other defined social groups.

${ }^{3}$ In particular, Rokeach's (1968) work on the general constructs of beliefs, values, etc. in the socio-psychological context, and Green's (1971) book on themes related to teaching, which include those of teaching and the formation of beliefs, the problem of knowledge certainty, truth and false belief.
} 
over a hundred papers concerning mathematics teachers beliefs, conceptions or/and attitudes. In 2009, in another publication, Beliefs and Attitudes in Mathematics Education: New Research Results (Maasz, Schlöglmann, 2009), nine of the thirteen chapters concentrate on teachers' beliefs, each of them scrutinizing different subgroups of teachers' mathematical beliefs. The original frameworks of Thompson (1992), Ernest (1989), etc. had been expanded, refined and contextualized, and the scope of research foci amplified.

In a wider mathematics education research context, da Ponte (2006) denotes three periods - 1977-1985, 1986-1994, and 1995-2005 - and identifies trends in each period, observing that published research papers dealing with teachers' knowledge (mathematical and of mathematics teaching), beliefs and conceptions, grew significantly in numbers compared to the "very few" (p. 463) in the first period. The second period also saw a few studies on the complex link between beliefs and teachers' practices which grew at an amazing rate in the third.

Within the wide range of disparate approaches to examining teachers' mathematical beliefs there are some common themes and questions to be found. The main aim of this article is to expose and present them to the reader as they appear and reappear in literature.

\section{What is A BeLIEF?}

One of the characteristics of beliefs research is the attitude toward the need to define or sufficiently describe what is meant by the term "beliefs". Defining the object of our study seems to be a prerequisite as well as the aim in some cases. Indeed, as Pajares (1992) stresses, it is inevitable that any research be preceded by "deciding what [researchers] wish belief to mean and how this meaning will differ from that of similar constructs". (p. 308). This decision seems to be given a varying degree of importance and meticulousness, ranging from the adoption of previously loosely defined constructs - such as Pajares' or Thompson's definition ${ }^{4}$ — and their inherent characteristics (e.g., Andrews, Hatch, 1999; Barkatsas, Malone, 2005; Leatham, 2006), to leaving the term itself undefined, focusing rather on the objects and characteristics of beliefs (e.g., Stipek et al., 2001; Speer, 2008), and/or attempting to arrive at a precise definition (Törner, 2002; Goldin, 2002) (see also da Ponte, Chapman, 2006).

Generally, it is agreed (McLeod, 2002; Furinghetti, Törner, 2002; Leatham, 2006) that the word conception be used as a construct containing beliefs as subsets, along with other subcategories such as knowledge, views, preferences. For example, we can find this quote in Furinghetti and Törner (2002) of Thompson's (1992) definition: "A teacher's conceptions of the nature of mathematics may be viewed as that teacher's conscious or subconscious beliefs, concepts, meanings, rules, mental images, and preferences concerning the discipline of mathematics." Forgasz and Leder (2002) consider various definitions, among them Rokeach's (1968, "a belief is any simple proposition, conscious or unconscious, inferred from what a person says or does, capable of being preceded by the phrase 'I believe that..."', p. 97) and Gopnik and Meltzoff's (1997, "Perception and belief, they contend, share many features: Both have a mind-to-world direction of fit - they involve changing representations

\footnotetext{
${ }^{4}$ Thompson's definition follows in the text, Pajares (1992) after much discussion concludes that "the result is a view of belief that speaks to an individual's judgment of the truth or falsity of a proposition" (p. 316).
} 
to fit the world. Both are indirectly reflected in action and behavior. Most significantly, both perception and belief may be subject to misrepresentation - with perceptual illusions we see what is not the case, just as with false beliefs we think what is not the case.", p. 97). ${ }^{5}$ Furinghetti and Törner (2002) discuss two other constructs from which beliefs are often distinguished: knowledge (e.g., considering beliefs as subjective knowledge and viewing knowledge as objective facts, within the limits of subjective philosophical definitions of both) and attitude (which brings in an element of affect). The affective component and its role in the teaching and learning process are highlighted by some researchers. Goldin (2002) expresses the interrelatedness of attitude, emotions and belief systems:

The consensus is that beliefs, attitudes and values are the consequence of an evolutionary process that involves all of an individual's experiences with mathematics throughout their entire life. An exception is emotions, which are based on an individual's general mental mechanisms, evoked when reacting to situational and local problems. Nevertheless, these reactions can also lead to longer-term consequences. (p. vii)

To address the place of affect, Phillip (2007) notes that beliefs "are more cognitive than attitudes and attitudes [do not fall under affect] because, although beliefs are considered component of affect by those studying affect, they are not seen in this way by most who study teachers' beliefs." (p. 259). This text conforms to his notion.

An interesting approach to formalizing the construct of beliefs can be found in Törner (2002) who devises a four-component mathematical model for any one belief and then assigns it a set of properties. We will return to the topic further in the text when discussing belief structures and systems.

The messiness (Pajares, 1992; Leder, Pehkonen, Törner, 2002) of the concept of belief does not appear to weigh too heavily on working with individual beliefs or sets of beliefs. We can now safely leave the academic debates and approach the subject of belief's objects and content in terms of its place within mathematics education (and, as stated earlier, as pertaining to the mathematics teacher domain). The basic outline is given by Ernest (1989) when he states that as relates to teaching mathematics, it makes sense to study teacher's views, conceptions or models of

- the nature of mathematics,

- the nature of mathematics teaching, and

- the process of learning mathematics.

Naturally, these broad categories contain many possibilities for exploration and have been further subcategorized. Pehkonen (2004) notices a trend to add further subcategories (especially including an affective domain): beliefs about mathematics education, beliefs about self, and beliefs about the social context. If we restrict ourselves to (teachers') mathematical beliefs, Goldin (2002) makes a "preliminary list" (p. 67) of sub-categories that also include affective (along with cognitive) elements:

- Beliefs about the physical world, and about the correspondence of mathematics to the physical world;

\footnotetext{
${ }^{5}$ For an extensive discussion of the definitions of the construct of beliefs see Furinghetti and Törner (2002) and Forgasz and Leder (2002), and, more recently, Philipp (2007).
} 
- Specific beliefs, including misconceptions, about mathematical facts, rules, equations, theorems, etc.;

- Beliefs about mathematical validity, or how mathematical truths are established;

- Beliefs about effective mathematical reasoning methods or strategies and heuristics;

- Beliefs about the nature of mathematics, including the foundations, metaphysics, or philosophy of mathematics;

- Beliefs about mathematics as a social phenomenon;

- Beliefs about aesthetics, beauty, meaningfulness, or power in mathematics;

- Beliefs about individual people who do mathematics, or famous mathematicians, their traits and characteristics;

- Beliefs about mathematical ability, how it manifests itself or can be assessed;

- Beliefs about the learning of mathematics, the teaching of mathematics, and the psychology of doing mathematics;

- Beliefs about oneself in relation to mathematics, including one's ability, emotions, history, integrity, motivations, self-concept, stature in the eyes of others, etc. (pp. 67-68)

From this comprehensive and arguably extendable inventory it is apparent that the object of mathematical beliefs can range from a very specific mathematical concept or process (e.g., the concept of infinity, or that of the operation of division) to a philosophical question (e.g., about the nature of mathematics), from a particular didactic strategy (e.g., using calculators) to a role of mathematics (e.g., in a person's life), etc.

\section{ISOLATED BELIEFS ARE NOT ENOUGH}

Before we approach the subject of belief structures (i.e., how all these different beliefs coexist within an individual's intellectual system), we need to look at some characteristics of beliefs that are relevant to educational research. The first has to do with the tangibility of beliefs. How does one identify a belief? The problem is that one holds beliefs without necessarily being conscious of them or without being able to articulate them. When prompted to do so, by the "belive" (or its contextual equivalent) statement, one can be expected to at best express a belief about an object (such as the effectiveness of learners' discovery in the process of learning about the Pythagorean theorem) or else to acknowledge that one cannot express it (e.g., when asked to express own views on the nature of mathematics), and at worst to completely misconsture it.

If we want to know about beliefs, we need to rely on inference. Specifically, we can either infer beliefs from people's actions and intentions or from what they say (Pajares, 1992). At the same time, inference is not a particularly reliable process, especially if the sources for it are few (Leatham, 2006). The methodological problem of belief recognition and inference has led to establishing a distinction between espoused (stated, consciously recognized) and enacted (inferred from observation) beliefs. Perhaps unsurprisingly, research into the link between teachers' espoused 
beliefs (what teachers state they believe, whether prompted or not) and enacted beliefs (what underlies their action and decision-making in practice) returns conflictive rather than confluent results (Handal, 2002; Barkatsas, Malone, 2005; Cooney, Wilson, 2002; Leatham, 2006; Liljedahl, 2008; Speer, 2008) ${ }^{6}$. These were originally serious epistemological findings indicating methodological flaws rather than explaining the role of teachers' beliefs in classrooms. In trying to account for them, the answers seem to lie in acknowledging that it is not individual, isolated beliefs that will provide insight into teacher's practice but rather the structure in which they are embedded and the way they come in and out of the decision-making process (Leatham, 2006; Beswick, 2012).

\subsection{Belief SYSTEMS - BELIEFS IN PRACTICE}

To illustrate what we mean by the importance of belief systems, let us consider a particular study: in Törner et al. (2002) a rough "network" of a particular teacher's beliefs is drawn out from interviews and lesson observations, connecting various issues of teaching mathematics. In this particular case, the object of the central belief group (referred to as "bundle") is the computer, and there are four other pedagogical-content belief bundles identified (discovery lessons, open lessons, motivation and reality-related lessons) to have a direct link to it. Interpreting the analysis, Törner et al. observe: "At first, beliefs centered on the role of the computer are dominant [and are central to] the lesson. As the lesson progressed, [...] the use of the computer became problematic and denoted the decisive turning point in the lesson when losing its central role. The moment the teacher realized that she could not achieve her central subject matter that is to introduce the term slope, she let the students simply switch off the computer. As the computer lost its important role, the belief bundles concerning open lessons, discovery lessons, and motivation played only a marginal role afterwards. [... In other words, all pedagogical content goals and beliefs lost their rather positive value and stepped aside to make room for subject matter goals and beliefs." (p. 416)

The fact that a person holds simultaneously a vast amount of (groups of) beliefs, some of them conflicting, is the focal point of several belief system theoretical models. Such models typically build on Green's (1971) metaphorical framework that assigns beliefs three dimensions: a) psychological strength, depending on how deeply they are rooted in the system that forms a person's conscious identity, how central they are to it, b) some beliefs derive from others, not necessarily following rules of logic or evidence, i.e., the logical implications between beliefs are also believed rather than objectively true, and finally c) the notion of beliefs existing in clusters (bundles, groups) that are likely to isolate themselves in various degrees from other clusters thus enabling contradictory beliefs to exist within one system.

To use the illustration given above, the psychological strength of subject matter beliefs was bigger than that of the pedagogical beliefs: the teacher held a belief that by using the computer she would be able to conduct a discovery lesson which in turn would lead to the pupil's understanding of the concept of slope (demonstrating the quasi-logical relationship between two beliefs) and the cluster of the identified pedagogical content beliefs, although at first linked to her content belief cluster, was easily isolated again when it came to making a decision about proceeding with the lesson. Similarly, Leatham (2006) calls for studying teacher belief system and

\footnotetext{
${ }^{6}$ There are also some studies that confirm alignment of expressed beliefs and actual practice in general terms (e.g. Stipek et al., 2001).
} 
practice as "sensible systems" assuming a consistency between the two and looking to explain rather than report any outward discrepancies. She demonstrates this consistency on a case of a teacher whose pedagogical beliefs about students' needs to feel successful dominated his mathematical beliefs about the process of learning. Instead of reporting inconsistency between the teacher's mathematical beliefs and his practice, perceiving the psychological strength and centrality of his pedagogical beliefs here makes perfect sense of his action.

\section{InVESTIGATIONS INTO MATHEMATICAL BELIEF GENESIS, EVOLUTION AND CHANGE}

Once mathematical beliefs are assigned (at least theoretically) a determinant role in teaching practice, it is natural that the interest of educators and researchers should be attracted by belief development and change, followed by their practical implications. How does a belief come to be? What influences the creation of a belief, what induces its change, what determines its strength? (Again, all these questions should be viewed within the context of belief structures, and form the driving force behind the study of the dynamics and structure within a system of beliefs.)

To outline the complexity of belief development, we'll use a model of factors influencing mathematics teachers' practice and mathematical beliefs designed by Raymond (1997) (see Figure 1) ${ }^{7}$. We will comment here on the belief-determining factors as situated in the body of research investigations:

1. We can see the central reciprocal relationship between beliefs and practice. Just as teacher's beliefs are viewed as crucial in the decision-making in teaching contexts, the practice itself has a belief-formative power. This becomes self-evident if we think of the process of teaching practice as epistemological: the experience of teaching, interacting with students and other belief subjects is bound to extend and/or vary mathematical beliefs of a teacher. Cross (2009) concludes that "[Experienced teachers'] beliefs were well-grounded and evidentially held, as they were based on their experiences with students throughout their careers." (p. 343). Jirotková (2012) talks about strengthening beliefs through reflective practice and "internalizing intuitive convictions".

2. School experiences, along with early childhood experiences form a category of factors that falls in the realm of student (or pupil) mathematical beliefs, whose rich body of literature falls beyond the scope of this paper. It is important, however, to look at these as determinant in the process of belief formation and as a guide in understanding the strength, centrality and resilience of some beliefs. The strong influence of past school and childhood experiences has been suggested, among others, by Harel (1993), Cooney and Wilson (2002) and Handal (2002) and confirmed, among others, by Cross (2009) and Frost (2010) who investigated the correlation of biographical factors and episodes and teaching approaches.

\footnotetext{
${ }^{7}$ Although this model is not all encompassing — for example, teacher's life experiences may influence their mathematical beliefs directly: to begin with, one can imagine a direct link between parenthood and change the mathematical beliefs of teachers — see e.g. Frost (2010); also, the model does not emphasize the cultural influence on teachers' beliefs (e.g. Correa et al., 2008) it will serve here as a guide through the research on belief evolution.
} 
3. Immediate classroom situations (students' abilities, attitudes, and behavior, time constraints, the mathematics topic at hand) seem to play their short term role in activating sets of beliefs, in establishing the context, as discussed in the belief structure section of this text.

4. Examining the element of teacher educational programs in the process of belief formation has, naturally, attracted the attention of many educators. In the following section we will give an outline of the results of this examination.

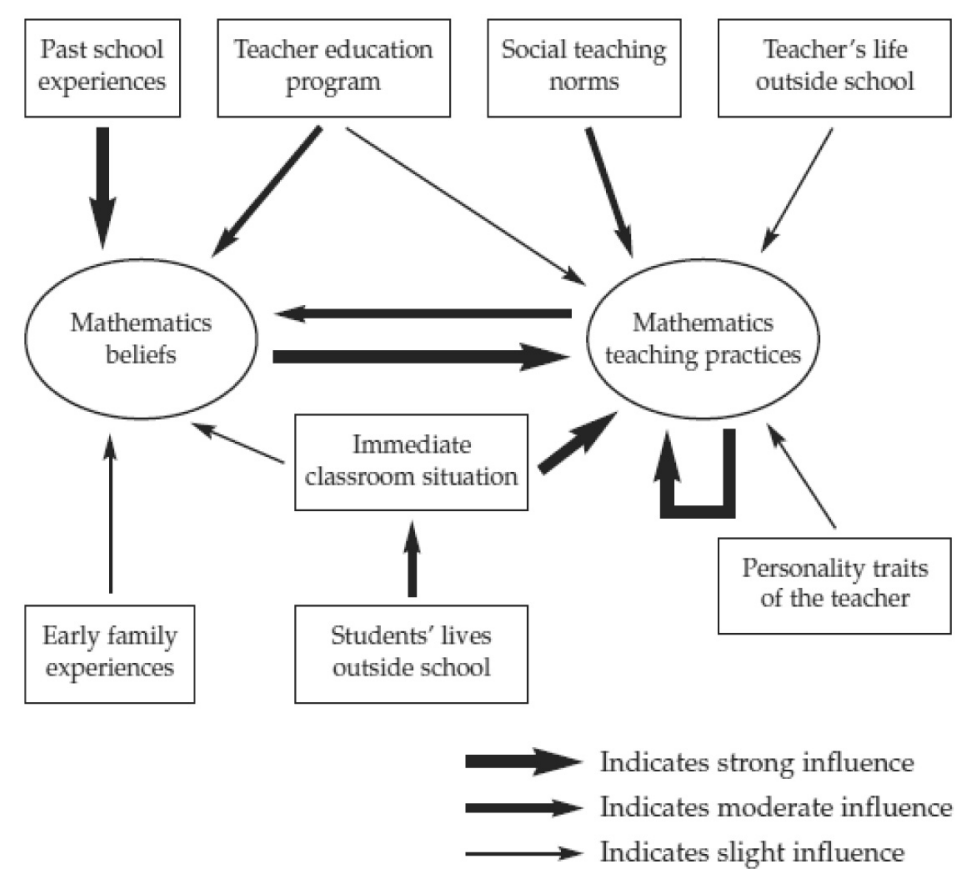

Figure 1: Factors influencing teacher's mathematical beliefs in Raymond's model

\subsection{CHANGING AND REFORMing MATHEMATICAL BELIEFS: STUDIES IN MATHEMATICAL TEACHER DEVELOPMENT}

In general, beliefs are considered to be resilient psychological constructs (Green, 1971; Cross, 2009). Pajares (1992) points out the phenomenon of assimilation and accommodation of new concepts and ideas: we are more likely to adapt these to our existing beliefs than modify what we believe. Research suggests that their change or development goes hand in hand with cognitive processes (Green, 1971; Goldin et al., 2009): they can only build on previously acquired beliefs and they are unlikely to be replaced by other beliefs unless they prove unsatisfactory, i.e., unless they are challenged. ${ }^{8}$

More specifically, da Ponte and Chapman (2006) and Philippou and Christou (2006) argue that change in beliefs in teachers will spring from conflicting situations, namely from the conflict between the teacher's intentions and the perceived reality of a classroom, while Hošpesová andTichá (2010) show how teacher's beliefs about the teaching of mathematics change with the deepening of their competence to pose problems ${ }^{9}$.

\footnotetext{
${ }^{8}$ Here we can appreciate the parallel with knowledge; indeed, we can see how knowledge may be considered indistinguishable from beliefs in research frameworks.

${ }^{9}$ In Trch and Zapotilova (2004) a similar effect is studied on student teachers' attitudes.
} 
The results of research undertaken to study influence of teacher or pre-service teacher development on beliefs are far from conclusive. They seem to confirm the belief resilience conjecture, and in terms of the above presented Raymond's model, neither of the two arrows originating in the teacher education program category can be assigned a secured thickness.

In her recent study, Cross (2009) finds that other factors, especially teaching experience, previous schooling and curricular and institutional constraints, dominate the teacher's decision-making process and their ability to subscribe to new practices. She reports on the effect of a reform-oriented professional support program on the actual practice of five secondary school mathematics teachers and concludes that "by the end of the project, the teachers ${ }^{10}[\ldots]$ were only beginning to question the effectiveness of their current practices, and [...] were not confident they could adopt these practices holistically" (p. 341), a result she attributes to the notion that "although the teachers welcomed new practices they were filtered through the old belief system, resulting in minimal change" (p.342) and adding that "evidence that contradicts teachers' current beliefs is an important component of the process, but alone will not lead to any real or sustained change." (p. 342)

Cross works with another significant assumption: that the teacher's conceptions of mathematics (what mathematics is and what it means to master it) determine their views of teaching and learning (the role of the teacher, practice, and understanding of concepts) and that the change of the former will result in alternation of the latter. The author further quotes previous research that documents the low efficiency of mathematics methodology courses and suggests that "targeting prospective teachers' beliefs through mathematics content courses [...] should result in greater success." (p. 342) This contrasts with Stehlíková (2004) who reports on a case of a student teacher who actively participated in a university mathematics course that adopted constructivist principles and although she appreciated the joy and satisfaction the discovery brought to her, she expressed her belief in the efficiency of traditional teaching (which she has experienced throughout her schooling, including university courses) and doubted that the constructivist approach could be suitable for pupils before they reach university.

Although contradictory on surface, these two findings can be understood as a) confirming the change-resistant character of beliefs rooted in past experience and b) pointing to the need of individualized approach wherever the change of beliefs is targeted by teacher development programs. Barešová and Tichá (2000) observe the existing prominence of beliefs about the procedural, formal nature of mathematics over newly acquired experiences in problem-solving and problem-posing learning environments in some teachers, while noting belief and practice development in others.

It is necessary to point out that there are also studies that do report conclusively on teacher mathematical belief change (Cobb, Gresalfi, 2011; Swan, Swain, 2010; Liljedahl, 2010). Swan and Swain (2010) studied pre- and post-tests of mathematical beliefs of teachers participating in a development program characterized as "an iterative, design-research process" for numeracy teachers of pupils above the age of 16. The results in (espoused) belief change aligned with results in practice development, as targeted by the program. Swan and Swain argue for an explanation of the above described lag in belief change: adopting Askew's et al. (1997) tripartite model of transmission, discovery and connectionist numeracy teachers' beliefs, they

\footnotetext{
${ }^{10}$ Those who held predominantly traditional beliefs and views.
} 
note a change in beliefs away from transmission towards discovery and connectionist views and from discovery to connectionist views. They specifically argue that the danger lies in the teacher not moving past the discovery "point"11, and that the change in practice must precede change in beliefs which, in turn will only happen under certain circumstances:

It might be assumed that in order to change a teacher's practice, one has to first change through persuasion his or her beliefs about teaching. [...] However, we would suggest that changes in beliefs are more likely to follow changes in practice, after the implementation of well-engineered, innovative methods, as processes and outcomes are discussed and reflected upon. (p. 175)

The discussion and reflection called for in the above lines resonates also with mathematics teacher development research in the Czech Republic: Hošpesová and Tichá (2006) report that it was through these two means that the teachers started to question their own beliefs and conceptions. Similarly, Kratochvílová (2004) describes the realization of change in a teacher's beliefs about mathematics pupils' ability to learn mathematics and the learning of mathematics as a process of constant reflection and collaborative reflection on practice and pupils' work. In addition, Hejný (2012), introducing a diagnostic tool for evaluating a teacher's teaching style includes teachers' beliefs and mathematical beliefs among the key elements in determining a teacher's practice (style), and thus sets a theoretical framework for exploring mathematical belief change in relation to practice.

\section{MethodologicAl APPROACHES}

If a precise definition of beliefs is not a subject of great concern for mathematical belief research, the methodological issues appear to be much more the center of debate and critical revisions. How can we identify such intimate, internal and individual entities as beliefs, conceptions and views? And when we do, what knowledge can we derive from our findings? Both qualitative and quantitative approaches have been adopted in search for answers to such questions. While qualitative inquiries have contributed to the development of theory and understanding of the intrinsic issues of teachers' mathematical beliefs (as discussed in the previous sections of this review), quantitative studies draw on their descriptive power to provide a picture of mathematics' teachers views and practices at a given time and within a selected community. In the next two sections we will look at both methodological approaches and their place in the research reviewed here, including their potential, benefits and limitations.

\subsection{Typologies IN QUANTITATIVE RESEARCH: TEACHERS' MATHEMATICAL BELIEFS IN BULK}

One of the features of quantitative research on mathematics teachers' beliefs is the aptitude to describe teachers in terms of their practice and beliefs, with the intention to make sense of what we can view as the essence of a teacher's teaching style. This is done by finding common characteristics and subsequent categorizing (this has actually been observed in both qualitatively and quantitatively designed research),

\footnotetext{
${ }^{11}$ As reported in Swan (2006), teachers did not associate the discovery orientation with particular practices, thus a shift in belief did not profess itself in effective teaching outcomes.
} 
Table 1: Belief typology according to Andrews and Hatch (1999)

\begin{tabular}{|l|l|l|}
\hline \multicolumn{3}{|c|}{ Conceptions of mathematics } \\
\hline $\begin{array}{l}\text { Identified type: } \\
\text { teachers view } \\
\text { mathematics }\end{array}$ & $\begin{array}{l}\text { Sample statement (espoused } \\
\text { belief/attitude) }\end{array}$ & $\begin{array}{l}\text { Theoretical type } \\
\text { (Ernst) }\end{array}$ \\
\hline As a life tool & M has many everyday uses & $\begin{array}{l}\text { Instrumentalist with } \\
\text { Problem-solving }\end{array}$ \\
\hline $\begin{array}{l}\text { As a service tool to } \\
\text { other areas of human } \\
\text { activity }\end{array}$ & $\begin{array}{l}\text { M teaching should take account of } \\
\text { other subject's needs }\end{array}$ & Instrumentalist \\
\hline $\begin{array}{l}\text { As a personal } \\
\text { economics tool }\end{array}$ & I enjoy checking my bank statements & Undecided prevalence \\
\hline $\begin{array}{l}\text { As a pleasurable and } \\
\text { diverse activity }\end{array}$ & $\begin{array}{l}\text { I enjoy rediscovering mathematics } \\
\text { I enjoy the precision of mathematics } \\
\text { M makes a unique contribution to } \\
\text { knowledge }\end{array}$ & Problem-solving \\
\hline \multicolumn{1}{|c|}{ Conception of mathematics teaching } \\
\hline $\begin{array}{l}\text { Identified type of } \\
\text { pedagogy adopted }\end{array}$ & $\begin{array}{l}\text { Sample statement (espoused } \\
\text { belief about classroom reality) }\end{array}$ & $\begin{array}{l}\text { Theoretical type } \\
\text { (Lerman) }\end{array}$ \\
\hline $\begin{array}{l}\text { Informal, focused on } \\
\text { process }\end{array}$ & $\begin{array}{l}\text { Investigational work is crucial in } M \\
\text { teaching }\end{array}$ & Fallibilist \\
\hline $\begin{array}{l}\text { Formal, focused on } \\
\text { skills }\end{array}$ & $\begin{array}{l}\text { Teachers should help students to } \\
\text { develop mental strategies }\end{array}$ & $\begin{array}{l}\text { Absolutist or } \\
\text { fallibilist }\end{array}$ \\
\hline $\begin{array}{l}\text { Focused on individual } \\
\text { learning }\end{array}$ & $\begin{array}{l}\text { Pupils all work on the same task } \\
\text { Pupils locate the equipment they } \\
\text { want }\end{array}$ & $\begin{array}{l}\text { Absolutist or } \\
\text { fallibilist }\end{array}$ \\
\hline $\begin{array}{l}\text { Creating collaborative, } \\
\text { open classroom }\end{array}$ & I sit and work with a group & Fallibilist \\
\hline $\begin{array}{l}\text { Valuing } \\
\text { mathematically } \\
\text { enriched environment }\end{array}$ & Puzzles or problems are on walls & $\begin{array}{l}\text { Fallibilist or } \\
\text { absolutist }\end{array}$ \\
\hline
\end{tabular}

which in turn can be used to describe a community targeted by research or compare characteristics across a range of subgroups (Andrews, 1999; Nisbet, Warren, 2000; Barkatsas, Malone, 2005; Hoz, Weizman, 2006; Duapete, 2008; Anjum, Munira, 2010).

Typically, such studies look at the bulk of mathematical beliefs as represented by beliefs about mathematics, mathematics learning and mathematics teaching, they identify major characteristics (typically statements) that represent polarized or hierarchical standpoints, e.g., fragmented and connectionist conceptions of mathematics (Crawford cited in Andrews, 1999, Cooney in Barkatsas and Malone, 2005). These are then presented to teachers in the form of a questionnaire (with a Likert scale or its variations) or/and are coded for in responses to structured questionnaires or interviews. As an example of such a typological study, let's consider Andrews and Hatch's (1999) large study of 577 secondary teachers in the UK. The data presented in their study comes from a questionnaire with statements focused around three topic sections: teacher's conceptions of mathematics, of mathematics teaching and their own classroom. The data is subjected to factor analysis and generates four types of conceptions of mathematics and five types of conceptions of mathematics teaching. See Table 1 for examples of belief statements associated with each type 
and its connection to a specific theoretical framework (i.e., Ernst's (1989) three types of views of mathematics and Lerman's (1990) fallibilist vs. absolutist model ${ }^{12}$ ) as discussed in the paper.

Andrews and Hatch's findings do not lead to clear correlation between specific types; rather, the conclusions stress the complexity of the topic and multiplicity of beliefs espoused by teachers. On their part, Barkatsas and Malone (2005) construct a questionnaire with 34 items that after factor analysis load on five types of orientations. These are consequently grouped into two main categories (see Table 2), according to teacher expressed agreement with mathematical belief-statements. The percentage depicts the part of the total of 465 participants that identified with each view, based on the factor analysis of their questionnaire choices.

Table 2: Views and teacher typology according to Barkatsas and Malone (2005)

\begin{tabular}{|l|l|c|l|}
\hline Orientation & View & $\mathbf{\%}$ & Sample belief statement \\
\hline $\begin{array}{l}\text { Contemporary - } \\
\text { constructivist }\end{array}$ & $\begin{array}{l}\text { Socio- } \\
\text { constructivist }\end{array}$ & $\mathbf{1 5}$ & $\begin{array}{l}\text { Justifying the mathematical statements } \\
\text { that a person makes is an important part } \\
\text { of mathematics }\end{array}$ \\
\cline { 2 - 4 } & $\begin{array}{l}\text { Dynamic } \\
\text { problem } \\
\text { driven }\end{array}$ & $\mathbf{2 3}$ & $\begin{array}{l}\text { Mathematics learning is enhanced by } \\
\text { challenging activities within a supportive } \\
\text { environment }\end{array}$ \\
\cline { 2 - 4 } & Cooperative & $\mathbf{5}$ & $\begin{array}{l}\text { All students are able to be creative and do } \\
\text { original work in mathematics }\end{array}$ \\
\hline $\begin{array}{l}\text { Traditional- } \\
\text { transmitting- } \\
\text { information } \\
\text { processing }\end{array}$ & $\begin{array}{l}\text { Static } \\
\text { transmission }\end{array}$ & $\mathbf{3 0}$ & $\begin{array}{l}\text { The most effective way to learn } \\
\text { mathematics is by listening carefully to } \\
\text { the teacher explaining a mathematics } \\
\text { lesson }\end{array}$ \\
\cline { 2 - 4 } & $\begin{array}{l}\text { Mechanistic } \\
\text { transmission }\end{array}$ & $\mathbf{2 7}$ & $\begin{array}{l}\text { Mathematics knowledge is the result of the } \\
\text { learner interpreting and organising the } \\
\text { information gained from experiences }\end{array}$ \\
\hline
\end{tabular}

In Hoz and Weizman (2006), a typology based on dichotomies in beliefs about the nature of mathematics (the dynamic and static conceptions of mathematics) and the teaching and learning of mathematics (open and closed conception) is assumed (see Table 3) but it is shown that only $25 \%$ of the 176 participants adhered to a type in both categories. Over a half of the teachers do not express adherence to a specific view of mathematics, and more than $50 \%$ do not subscribe to a particular mathematics teaching conception (as based on the collection of belief statements provided by the survey).

These three examples were chosen to offer the reader a glimpse at the complexity of methodological issues when it comes to identifying mathematical beliefs within a larger teacher community, with the available tool of questionnaires. The content subjectivity of the survey items along with a minimal interpretative power of the answer data as far as the actual teaching reality is concerned are but the most apparent drawbacks to questionnaire based research design. ${ }^{13}$ Nevertheless, their

\footnotetext{
${ }^{12}$ To give a rough description of the two extreme theoretical types: an absolutist believes that mathematics is a certain, abstract entity where values (personal and social) are not taken into account, a fallibilist views mathematics as an activity and a problem-solving process where truth is negotiable. (Lerman, 1990)

${ }^{13}$ For an interesting attempt at creating a collection of instruments to validate questionnaire prompted data about teachers' mathematical beliefs see Swan (2006). Also, an alternative to Likert scale belief surveys is proposed by Philipp (described in Philipp, 2007).
} 
Table 3: Typology of teachers' conceptions of mathematics according to Hoz and Weizman (2006)

\begin{tabular}{|l|l|}
\hline Conception & Sample belief statements \\
\hline Dynamic conception of $\mathbf{M}$ & $\begin{array}{l}\text { Uncertainty is inherent in the discipline of } M . \\
\text { The difficulty of } M \text { is not unique, it exists in other } \\
\text { domains. }\end{array}$ \\
\hline Static conception of $\mathbf{M}$ & $\begin{array}{l}\text { Mathematics is a priori and infallible. } \\
\text { Mathematics is objectively difficult. }\end{array}$ \\
\hline $\begin{array}{l}\text { Open conception of } \mathbf{M} \\
\text { teaching }\end{array}$ & $\begin{array}{l}\text { Teaching raises conflicts and doubts in the students' } \\
\text { minds with regards to mathematical content and } \\
\text { procedures. }\end{array}$ \\
\hline $\begin{array}{l}\text { Closed conception of } \mathbf{M} \\
\text { teaching }\end{array}$ & $\begin{array}{l}\text { Posing open questions and inquiry problems is } \\
\text { designed for strong students. }\end{array}$ \\
\hline
\end{tabular}

strength needs to be seen in contributing to general knowledge and understanding of a given community, and the data and results obtained should be considered an important artifact in the socio-historical context of mathematics education (Rösken et al., 2009; Wilson, Cooney, 2002).

\subsection{TyPOLOGIES AND QUALITATIVE RESEARCH: INFERRING TEACHERS' MATHEMATICAL BELIEFS}

Typologies are not a domain of quantitative research only. To study isolated beliefs makes sense when we want to top-down describe adherence to very specific beliefs (the purposes and limitations of such approach were illustrated above). On the other hand, qualitative research of beliefs and practices engages in discovering the ways beliefs can be inferred from actions and expressed opinions, including intentions of practice. Typologies here are typically constructed to provide better insight into the structure and characteristics of beliefs, or to evaluate the tools used for belief inference.

Renne (1992) prompts teachers to write in detail about a successful lesson they have taught, and to express what they hope their students will have learned by the end of a course. Her analysis of the data leads to four two-dimensional categories based on beliefs about the nature of (mathematical) knowledge and the purpose of (mathematical) school knowledge; she labels them as Conveyor, Facilitator, Allower and Organizer. Her study includes validating interviews that give a tentative result of consistency. Stipek et al. (2001) combine inference from questionnaires and lesson observation; they find a strong association between beliefs forming particular sets that can be viewed as defining two extreme conceptions of teaching mathematics: "traditional" (p. 216) and "inquiry-oriented, constructivist" (p. 217). Uncharacteristically, they confirm the alignment of these two conceptions with the teachers' practice. Eichler (2006) focuses on "the teachers' planning of mathematics instruction, thus, in a psychological sense, on intentions of action which escape observation" (p. 1), i.e., he argues that individual curricula can be understood as teachers' belief systems. He studies the role mathematical beliefs, and in particular beliefs connected to probability and statistics, play in an individual teacher's planning (i.e., intention of practice) and he arrives at four distinctly characterized types of teacher's approaches: traditionalists, application-preparers, every-day-lifepreparers, and structuralists. Liljedahl (2008) engages in-service secondary teachers 
in a debate about specific pre-service teachers' espoused beliefs about the nature of mathematics and their simultaneously prompted intentions of teaching practice. From this debate Liljedahl infers a system of beliefs based on differences (e.g., between ideal teaching practice vs. actual teaching, between mathematics and school mathematics, etc.). Cross (2009) derives a belief classification where the beliefs about the nature of mathematics and mathematical expertise (what it means to be good at mathematics) play a central role and influence beliefs about teaching and learning. Her study, based on data from surveys, observations and interviews, divulges the descriptions of three types of belief systems: traditional, progressive and separated (mixed). Finally, adopting the theory of sensible systems discussed above, Beswick (2012) endeavors to identify mathematical beliefs central to creating constructivist classroom environment. Although we have to allow for contextual considerations, the beliefs identified by her "may be generalizable to other contexts and even predictive of teachers likely to create classroom environments [consistent with the principles of constructivism]".

It is important to remember that the above described typologies and catalogues are of mathematical beliefs teachers hold (or profess to hold) and the beliefs they hold about (their) teaching practice. They are not typologies of their teaching practice, although often the two interrelate.

\section{CONCLUDING REMARKS}

In the light of the previous pages, it is safe to state that there are as many belief objects as there are questions. This, of course, is as true in mathematics education as in many other areas of human mental activity. The shift in mathematics education research in the past decades has been to look at a teacher and his practice through his/her beliefs (and attitudes and emotions). In that sense, beliefs are not a novel construct but rather an acknowledged variable, or, at times, a paradigm that has been helping to frame investigations into the world of mathematics teaching. However, as Skott (2009) duly warns, one of the conclusions that should be drawn from this research is that mathematical beliefs cannot be taken as the answer to explaining teachers' practice and/or classroom.

This literature review makes an attempt at mapping out the main features of field research conducted in the past decades in the area of teacher's mathematical beliefs as well as giving an outline of main theoretical frameworks that underpin it. The reader must be advised that the actual body of this particular area of research and corresponding literature exceeds by far the list of citations at the bottom of this article. In fact, over 16 years ago, Pehkonen and Törner (1996) declared that when trying to sort out research papers on mathematical beliefs "it was impossible to gather and classify all the information [...] since the research on mathematical beliefs done in all countries seems to be huge". Bearing such a predicament in mind, the given review has opted for presenting a set of studies and papers in order to a) provide illustrative cases relevant to specific phenomena - such as the definition of the subject of study, methodological issues, and considerations of practical applications - rather than generalizing and detaching them from research and educational reality, and b) to represent the work of various important working groups across the international research community.

The themes selected here were deemed significant because they addressed both general characteristics (belief nature and structure, belief birth and development) 
as well as specific content and roles (belief typologies and beliefs-practice relationship) while keeping the content relevant to mathematics education and introducing a variety of research designs. Qualitative designs have been invaluable in deepening our understanding of teachers' mathematical beliefs in terms of their characteristics, development and role in a teacher's practice. Quantitative design has provided opportunities for description of particular domains of beliefs, and the potential of comparative investigations. A main importance of typological studies (both quantitative and qualitative) is to gain insight in the sphere of philosophical belief structure and tools for determining and classifying a teacher's style and teacher personal philosophies, both confirming an existing theoretical framework by fieldwork, and constructing new theoretical frameworks and classifications based on data yielded in such inquiries (Forgasz, Leder, 2002; Speer, 2008; Rösken, Törner, Goldin, 2009).

Some of the particular interests of teachers' mathematical belief research not discussed in detail here include: 1) the centrality of beliefs concerning the nature of mathematics and/or school mathematics in mathematics teachers' practice, 2) the affective domain of mathematical beliefs, 3) the socio-culturally descriptive potential of belief research, particularly, international comparison studies and quantitative research done on national levels or across other large institutions. All of these are fascinating and rich subjects of investigation and deserve to be discussed in detail; however, they are beyond the scope of this review.

Having reviewed relevant research conducted in the Czech Republic, we may conclude that many studies stem from and are concerned with the valuable practical application in the area of mathematics teacher development, although there are a few quantitative studies that touch upon the topic of Czech teachers' mathematical beliefs as well. ${ }^{14}$

\section{BIBLIOGRAPHY}

ANDREWS, P., HATCH, G. A New Look at Secondary Teachers' Conceptions of Mathematics and its Teaching. British educational research journal. 1999, roč. 25, č. 2 .

ANJUM, H., MUNIRA, A. Teachers' Knowledge about the Nature of Mathematics: A Survey of Secondary School Teachers in Karachi, Pakistan. Bulletin of Education and Research. 2010, roč. 32, č. 2, s. 45-61.

ASKEW, M., BROWN, M., WILIAM, D., RHODES, V., JOHNSON, D. Effective teachers of numeracy: final report. London : King's College, School of Education, 1997.

BAREŠOVÁ, M., TICHÁ, M. Cultivation of student's and teacher's beliefs about mathematics education. In Research on Mathematical Beliefs. Proceedings of the MAVI-9 European Workshop, G. Mercator Universität, Duisburg, 2000, s. 96-102.

BARKATSAS, A., MALONE, J. A. Typology of Mathematics Teachers' Beliefs about Teaching and Learning Mathematics and Instructional Practices. Journal for Research in Mathematics Education. 2005, roč. 17, č. 2, s. 69-90.

\footnotetext{
${ }^{14}$ In particular, Janík et al. (2011), in studying teachers' attitudes towards curricular changes, finds that official curricular documents have a much smaller impact on teachers' practice and decision-making than their conceptions of the respective subjects. Elsewhere, Straková (2007) reports on the particularities of Czech mathematics teachers' belief about the innate nature of mathematical capabilities of pupils.
} 
BISHOP, Alan J. Mathematical enculturation: a cultural perspective on mathematics education. Boston : Kluwer Academic Publishers, 1988.

BROUSEAU, B. A., FREEMAN, D. J. How do teacher education faculty members define desirable teacher beliefs? Teaching and teacher education. 2001, č. 17, $267-273$.

COONEY, T., WILSON, M. Mathematics Teacher Change and Developments. In Pehkonen, E., Leder, G. C., Törner G. (eds) Beliefs: a hidden variable in mathematics education? Dordrecht : Kluwer Academic Publishers, 2002, s. 127-147.

COONEY, T. J. A beginning teacher's view of problem solving. Journal for Research in Mathematics Education. 1985, roč. 16, č. 5, 324-336.

CORREA, Ch. A., PERRY, M., SIMS, L. M., MILLER, K. F., FANG, G. Connected and culturally embedded beliefs: Chinese and US teachers talk about how their students best learn mathematics. Teaching and Teacher Education. 2008, roč. 24, č. 1 , s. $140-153$.

CROSS, Dionne I. Alignment, cohesion, and change: Examining mathematics teachers' belief structures and their influence on instructional practices. Journal of Mathematics Teacher Education. 2009, roč. 12, č. 5, s. 325-346.

DA PONTE, J., CHAPMAN, O. Mathematics teachers' knowledge and practices. In Boero, P., Gutierrez, A.(eds.) Handbook of research on the psychology of mathematics education: past, present and future. Rotterdam : Sense publishers, 2006, s. $461-493$.

DOSSEY, J. The nature of mathematics: its role and its influence. In Grouws, D. A. Handbook of Research on Mathematics Teaching and Learning. New York: Macmillan, 1992, s. 39-48.

DUAPETE, P. A. Comparing Teachers' Beliefs about Mathematics in Terms of Their Branches and Gender. Hacettepe University Journal of Education. 2008, č. 35, s. $87-97$.

EICHLER, A. Individual Curricula: Beliefs Behind Teachers' Beliefs. In Rossman, A. , Chance, B. Proceedings of the Seventh International Conference on Teaching Statistics. Salvador, Brazil : ISI, IASE, 2006, s. 1-6.

Dostupné z: 〈http://www.stat.auckland.ac.nz/ iase/publications 〉.

ERNEST, P. Problem solving in context(s). In Charles, R. I., Silver, E. A. The Teaching and assessing of mathematical problem solving. Reston, Va. : NCTM, 1988, s. 82-92.

ERNEST, P. The impact of beliefs on the teaching of mathematics. In Ernest, P. Mathematics teaching: the state of the art. New York : Falmer Press, 1989, s. 249-254.

ERNEST, P. The philosophy of mathematics education. New York : Falmer Press, 1991.

FISHBEIN, M., AJZEN, I. Belief, attitude, intention, and behavior: an introduction to theory and research. Reading, Mass. : Addison-Wesley Pub. Co., 1975.

FORGASZ, H., LEDER, G. Measuring Mathematical Beliefs and Their Impact on the Learning of Mathematics: A New Approach. In Pehkonen, E., Leder, G. C., 
Törner, G. (eds) Beliefs: a hidden variable in mathematics education? Dordrecht : Kluwer Academic Publishers, 2002, s. 95-113.

FROST, J. H. Looking through the lens of a teacher's life: The power of prototypical stories in understanding teachers' instructional decisions in mathematics. Teaching and teacher education. 2010, roč. 26, č. 2.

FURINGHETTI, F., PEHKONEN, E. Rethinking Characterizations of Beliefs. In Pehkonen, E., Leder, G. C., Törner, G. (eds) Beliefs: a hidden variable in mathematics education? Dordrecht : Kluwer Academic Publishers, 2002, s. 39-57.

GOLDIN, G. Affect, Meta-Affect, and Mathematical Belief Structures. In Pehkonen, E., Leder, G. C., Törner, G. (eds) Beliefs: a hidden variable in mathematics education? Dordrecht : Kluwer Academic Publishers, 2002, s. 59-72.

GREEN, T. F. The activities of teaching. New York : McGraw-Hill, 1971.

GRESALFI, M. S., COBB, P. Negotiating Identities for Mathematics Teaching in the Context of Professional Development. Journal for Research in Mathematics Education. 2011, roč. 42, č. 3, s. 270-304.

HANDAL, B. Teachers' Mathematical Beliefs: A Review. The Mathematics Educator. 2002 , roč. 13 , č. 2 , s. $47-57$.

HAREL, G. On teacher education programs in mathematics. International Journal for Mathematics Education in Science and Technology. 1993, č. 25, s. 113-119.

HEJNY, M. Cognitive goals and teaching styles in mathematics education. Orbis Scholae. roč. 6, č. 2, 2012 [in print].

HOŠPESOVÁ, A., TICHÁ, M. Problem Posing, a Way to Teachers' Change. In Proceedings of the ATEE Winter Conference 2010: Early Years, Primary Education and ICT, Univerzita Karlova v Praze, Praha, 2010, s. 41-51.

HOZ, R., WEIZMAN, G. A revised theorization of the relationship between teachers' conceptions of mathematics and its teaching. International Journal of Mathematical Education in Science and Technology. 2008, roč. 39, č. 7, s. 905-924.

JANÍK, T., KNECHT, P. NAJVAR, P., aj. Kurikulární reforma na gymnáziích: výzkumná zjištění a doporučení. Pedagogická orientace. Praha : Ceská pedagogická společnost, 2011, roč. 21 , č. 4 , s. 375-415.

JIROTKOVÁ, D. Tool for diagnosing the teacher's educational style in mathematics. Orbis Scholae. roč. 6, č. 2, 2012 [in print].

KAGAN, D. M. Implication of Research on Teacher Belief. Educational Psychologist. 1992 , roč. 27 , č. 1 , s. 65-90.

KRATOCHVÍLOVÁ, J. Jak Klára měnila svě pedagogické přesvědčení. Hejný, M., Novotná, J., Stehlíková, N. Dvacet pět kapitol z didaktiky matematiky. Praha : Univerzita Karlova v Praze - Pedagogická fakulta, 2004, s. 299-310.

KUHS, T., BALL, D. Approaches to teaching mathematics: Mapping the domains of knowledge, skills and dispositions. East Lansing, MI : Michigan State University, 1986.

LEATHAM, K. R. Viewing Mathematics Teachers' Beliefs as Sensible Systems. Journal of Mathematics Teacher Education. 2006, roč. 9, č. 1, s. 91-102. 
LEDER, G. C., PEHKONEN, E., TOR̄NER, G. Beliefs: a hidden variable in mathematics education? Boston : Kluwer Academic Publishers, 2002.

LERMAN, S. Alternative perspectives of the nature of mathematics and their influence on the teaching of mathematics. British Educational Research Journal. 1990, roč. 16 , č. 1 , s. $53-67$.

LILJEDAHL, P. Teachers' insights into the relationship between beliefs and practice. In Maasz, J., Schlöglmann, W. Beliefs and attitudes in mathematics education: new research results. Rotterdam : Sense publishers, 2008, s. 33-44.

LILJEDAHL, P. Noticing rapid and profound mathematics teacher change. Journal of Mathematics Teacher Education. 2010, roč. 13, č. 5, s. 411-423.

MAASZ, J., SCHLÖGLMANN, W. Beliefs and attitudes in mathematics education: new research results. Rotterdam : Sense publishers, 2009.

MCLEOD, D., MCLEOD. Synthesis - Beliefs and Mathematics Education: Implications for Learning, Teaching, and Research. In Pehkonen, E., Leder, G. C., Törner, G. (eds) Beliefs: a hidden variable in mathematics education? Dordrecht : Kluwer Academic Publishers, 2002, s. 115-123.

MCLEOD, D. B. The role of affect in mathematical problem solving. In McLeod, D. B., Adams, V. M. Affect and mathematical problem solving: a new perspective. New York: Springer-Verlag, 1989, s. 20-36.

MELTZOFF, A., GOPNIK, N. Words, thoughts, and theories. Cambridge, Mass : MIT Press, 1997.

NISBET, S., WARREN, W. Primary school teachers' beliefs relating to mathematics, teaching and assessing mathematics and factors that influence these beliefs. Mathematics Teacher Education and Development. 2000, č. 2, s. 34-47.

PAJARES, M. F. Teachers' Beliefs and Educational Research: Cleaning Up a Messy Construct. Review of Educational Research. 1992, roč. 62, č. 3, s. 307-332.

PEHKONEN, E., TÖRNER, G. Introduction to the theme: Mathematical Beliefs. International Reviews on Mathematics Education: Analysis: Mathematical Beliefs. 1996, roč. 28 , č. 4, s. 99-108.

PEHKONEN, E. State-of-the-art in mathematical beliefs research: Regular Lecture. In ICME-10 proceedings: ICME 10 2004. [online]. 2008 [cit. 2012-05-08]. Dostupné z 〈http://www.icme10.dk/proceedings/pages/side01main.htm $\rangle$.

PERRY, W. G. Forms of intellectual and ethical development in the college years: a scheme. New York : Holt, Rinehart and Winston, 1970, $256 \mathrm{s.}$

PHILIPP, R. A. Mathematics Teacher's Beliefs and Affect. In Lester, F. K. (ed). Second handbook of research on mathematics teaching and learning: a project of the National Council of Teachers of Mathematics. Charlotte, NC : Information Age Pub., 2007, s. 257-315.

PHILIPPOU, G., CHRISTOU, C. A Study of the Mathematics Teaching Efficacy Beliefs of Primary Teachers. In Pehkonen, E., Leder, G. C., Törner, G. (eds). Beliefs: a hidden variable in mathematics education? Dordrecht : Kluwer Academic Publishers, 2002, s. 211-231.

POLYA, G. Mathematical discovery: On understanding, learning, and teaching problem solving (Vol. 2). New York : Wiley, 1965. 
RAYMOND, A. M. Inconsistency between a beginning elementary school teacher's mathematics beliefs and teaching practice. Journal for research in mathematics education. 1997 , roč. 28 , č. 5 , s. 550-576.

RENNE, C. Elementary School Teachers' Views of Knowledge Pertaining to Mathematics. Paper presented at the Annual Meeting of the American Research Association (San Francisco, CA, April 1992). [online]. 1992 [cit. 2012-05-16]. Dostupné z: $\langle$ http://www.eric.ed.gov $\rangle$.

ROKEACH, M. Beliefs, attitudes, and values: a theory of organization and change. San Francisco : Jossey-Bass, 1976.

RÖSKEN, B., TÖRNER, G., GOLDIN, G. Beliefs - No Longer a Hidden Variable in Mathematical Teaching and Learning Process. In Maasz, J., Schlöglmann, W. Beliefs and attitudes in mathematics education: new research results. Rotterdam : Sense publishers, 2009, s. 1-15.

SCHOENFELD, A. H. Learning to think mathematically: problem solving, metacognition, and sense making in mathematics. In Grouws, D. A. Handbook of Research on Mathematics Teaching and Learning. New York : Macmillan, 1992, 334-370.

SCHOENFELD, A. H. Beyond the purely cognitive: Belief systems, social cognitions, and metacognitions as driving forces in intellectual performances. Cognitive Science. 1983, č. 7, s. 329-363.

SKOTT, J. Contextualising the notion of 'belief enactment'. Journal of Mathematics Teacher Education. 2009, roč. 12, č. 1, s. 27-46.

SPEER, N. M. Connecting Beliefs and Practices: A Fine-Grained Analysis of a College Mathematics Teacher's Collections of Beliefs and Their Relationship to His Instructional Practices. Cognition and Instruction. 2008, roč. 26, č. 2, s. 218-267.

STEHLÍKOVÁ, N. Structural Understanding in Advanced Mathematical Thinking. Praha : Univerzita Karlova v Praze Pedagogická Fakulta, 2004.

STIPEK, D. J., MACGYVERS, V. L., SALMON, J. M., et al. Teachers' beliefs and practices related to mathematics. Teaching and Teacher Education. 2001, č. 17, s. $213-226$.

STRAKOVÁ, J. The Impact of the Structure of the Education System on the Development of Educational Inequalities in the Czech Republic. Czech Sociological Review. 2007, roč. 43, č. 3, s. 589-610.

SWAN, M. Designing and using research instruments to describe the beliefs and practices of mathematics teachers. Research in Education. 2006, č. 75, s. 58-127.

SWAN, M., SWAIN, J. The impact of a professional development programme on the practices and beliefs of numeracy teachers. Journal of Further and Higher Education. 2010, roč. 34, č. 2.

THOMPSON, A. G. Teachers' beliefs and conceptions: A synthesis of research. In Grouws, D. A. Handbook of research on mathematics teaching and learning. New York : Macmillan, 1992, 127-146.

THOMPSON, A. G. The relationship of teachers' conceptions of mathematics and mathematics teaching to instructional practice. Educational Studies in Mathematics. 1984 , č. $15,105-127$. 
TICHÁ, M., HOŠPESOVÁ, A. Qualified Pedagogical Reflection as a Way to Improve Mathematics Education. Journal of Mathematics Teacher Education. 2006, roč. 9, č. 2 , s. $129-156$.

TÖRNER, G., ROLKA, K., RÖSKEN, B., SRIRAMAN, B. Understanding a Teacher's Actions in the Classroom by Applying Schoenfeld's Theory Teaching-InContext: Reflecting on Goals and Beliefs. Sriraman, B., English, L. Theories of mathematics education: seeking new frontiers. New York : Springer, 2010, s. $401-420$.

TÖRNER, G. Mathematical Beliefs - A Search for a Common Ground: Some Theoretical Considerations on Structuring Beliefs, Some Research Questions, and Some Phenomenological Observations. In Pehkonen, E., Leder, G. C., Törner, G. (eds). Beliefs: a hidden variable in mathematics education? Dordrecht : Kluwer Academic Publishers, 2002, s. 73-94.

TRCH, M., ZAPOTILOVÁ, E. Problémy, výzvy a diskuse - prostředky motivace při vyučování matematice. In Hejný, M., Novotná, J., Stehlíková, N. Dvacet pět kapitol z didaktiky matematiky. (1. díl). Praha : Univerzita Karlova v Praze - Pedagogická fakulta, 2004, s. 203-212.

\section{ACKNowledgement}

The article was supported by research grant GA ČR P407/11/1740.

The author would like to thank Marie Tichá for providing an important insight into the relevant Czech literature, and to express deep gratitude to Nada Vondrová for her invaluable guidance and support in writing this review.

Mgr. Jana Žalská - E-mail: zalska@hotmail.com

Charles University in Prague, Faculty of Education, Czech Republic 